\title{
XRCC1 Gene
}

National Cancer Institute

\section{Source}

National Cancer Institute. XRCC1 Gene. NCI Thesaurus. Code C19675.

This gene is involved in single-strand DNA break repair. 